\title{
REFLECTION
}

\section{Identifying and Addressing Potential Conflict of Interest: A Professional Medical Organization's Code of Ethics}

\author{
Lori Heim, MD, FAAFP \\ President, American Academy of Family \\ Physicians, Leawood, Kansas
}

Conflicts of interest: The author is president of the American Academy of Family Pbysicians.

\section{CORRESPONDING ADDRESS}

Lori Heim, MD, FAAFP

American Academy of Family Physicians 11400 Tomahawk Creek Pkwy

Leawood, KS 66211-2672

lheim@aafp.org

\begin{abstract}
The new Consumer Alliance agreement between the American Academy of Family Physicians (AAFP) and The Coca-Cola Company provides a valuable opportunity to illustrate AAFP's adherence to its ethical foundation, demonstrate the AAFP's commitment to serving physicians and the public, and maintain the trust Americans put in their family physicians and the organization that represents them. Throughout the development of this program, as well as in all business interactions, the AAFP consistently addresses possible conflict of interest openly and directly, sharing with our members and the public exactly what measures we take to ensure that, in fact, no unethical conduct or breach of trust would-or will in the future-occur. In this case, the AAFP saw a public health and education need that was both unmet and undermined by the barrage of marketing messages and confusing information, and acted to fill that need. In so doing, the AAFP hewed to its high ethical standards, its core values, and its mission in the decisions made and the actions that followed.
\end{abstract}

Ann Fam Med 2010;8:359-361. doi:10.1370/afm.1146.

See Brody for a related article: http://www.annfammed.org/cgi/content/full/8/4/354.

\section{INTRODUCTION}

I

$\mathrm{n}$ his essay, ${ }_{1}^{1}$ Dr Brody contends the appearance of a conflict of interest, in and of itself, constitutes actual conflict of interest. In short, a person's perception of another's behavior-even absent relevant information related to the behavior or its outcome-determines whether a conflict exists. A person's projection of his own assumptions about another's motivation, however, cannot be the only factor in determining conflict of interest. Mere accusation or conjecture is hardly evidence.

Brody himself acknowledges, "It is true that where a conflict of interest exists, no actual unethical behavior has necessarily arisen. There may be a strong temptation to serve a competing interest instead of doing one's duty, and yet one may have successfully withstood the temptation." The actions of the American Academy of Family Physicians (AAFP) with regard to The Coca-Cola Company (TCCC) agreement have, indeed, proven this point.

Integral to this discussion is the transparency of the interaction, the rules governing the interaction, and the outcome of the agreement. Examined only in a philosophical vacuum, issues of conflict of interest and the underlying ethics governing behavior become an ideological straitjacket.

Simply entering into the Consumer Alliance Program (CAP) with the TCCC does not define further behavior by the American Academy of Family Physicians (AAFP), as Brody would suggest. To gauge an individual 
or organization's ethics, one must view its behavior over time, define the goal of that behavior, and compare the outcome with the mission and values. Within this context, one can determine whether the assumption or appearance of conflict of interest or ethical lapse was, in fact, correct.

We agree that appearances matter. This is precisely why AAFP consistently addresses possible conflict of interest openly and directly, sharing with our members and the public exactly what measures we take to ensure that, in fact, no unethical conduct or breach of trust would-or will in the future-occur.

We also agree that trust does have bearing. The Academy's 60 years of advocating on behalf of family medicine, providing high-quality lifelong learning opportunities for family physicians, and developing resources to help Americans improve their health have built a solid foundation of trust among physicians and their patients

Although the AAFP-TCCC agreement did raise initial questions, the ultimate outcome of the contract illustrated AAFP's adherence to its ethical foundation, demonstrated the AAFP's commitment to serving physicians and the public, and maintained the trust Americans put in their family physicians and the organization that represents them.

The AAFP maintains this trust by following its policy of transparency, immediately answering critics' questions, and, in keeping with its principles and its agreement with TCCC, developing unbiased educational materials that help patients make good nutrition decisions.

In contrast, Brody has failed to bring forth evidence that the TCCC contract interfered with AAFP's ability to meet its mission. Moreover, he offers no evidence of long-term harm resulting from early, uninformed reaction to the AAFP-TCCC agreement.

\section{ORGANIZATIONAL ETHICS AND ACTIONS}

Since its founding, the AAFP has held the health of the public as a core value. The organization's mission ${ }^{1}$ is centered on improving the health of patients, families, and communities. To that end, the organization has established lifelong learning requirements and continuing education opportunities for members, advocated on behalf of patient access to health care, and developed resources to help Americans adopt healthful habits and actively participate in their own health care.

Americans are bombarded with advertisements exclaiming the medical superiority of one product over another. Fad diets are touted as the solution to weight problems. Today's medical research findings contradict conventional wisdom or even research findings from 20 years ago. In the midst of that overwhelming clutter, the AAFP launched FamilyDoctor.org to help patients and their families sort through the chaff.

FamilyDoctor.org has won numerous national awards ${ }^{2}$ for its service as a clearinghouse of evidencebased and peer-reviewed information about healthful living; the symptoms, diagnosis, and treatment of illness; and patients' communication with their primary care physicians and health care team.

The need to improve Americans' nutrition and weight control dominates today's public health discussions. Nearly $34 \%$ of adults ${ }^{3}$ and $17 \%$ of children and adolescents aged 2 to 19 years are obese. ${ }^{4}$ Despite the wealth of articles, advice, and guidance on nutrition and weight control, 52\% of Americans have said they need more information about nutrition and healthy eating. ${ }^{5}$

Clearly, Americans want and need more factual information about healthful eating habits and the role of nutrition in weight control. By establishing the CAP, the AAFP augmented its outreach to Americans and expanded its ability to identify, peer-review, and synthesize health information into a comprehensive, coherent, and patient-friendly format. The alliance itself was based on an explicit and transparent agreement.

As with every interaction with outside organizations and individuals, the AAFP recognizes that agreements through the CAP create a potential for and could conjure an appearance of conflict of interest.

A close review of the TCCC agreement shows that its provisions comport with the strict internal and external standards_-including the Accreditation Council for Continuing Medical Education's Standards for Commercial Support, the American Medical Association's Council on Ethical and Judicial Affairs ethics policies, and other laws, regulations, and codes that pertain to conflict of interest. This management strategy has successfully guided AAFP interactions for more than 60 years. It has a long and honorable history among the professions and in law and government. Moreover, other organizations' lapses in the design or enforcement of their management strategies have been the driving force behind AAFP's own openness and strict guidelines for CAP participation.

\section{CORE VALUES, ORGANIZATIONAL MISSION}

Abandoning a successful, strictly enforced policy of transparency and management of potential conflict of interest to maintain an appearance of purity does little more than assuage perceptions. Divesting of collaborative alliances formed to improve public health does not meet patients' or the community's need for unbiased, understandable, and useful health information. 
Thus, in adherence to its strict conflict-of-interest policy, the AAFP specifically stipulated that any FamilyDoctor.org content supported through the CAP would be controlled by the AAFP, peer-reviewed for accuracy and objectivity by outside reviewers, and devoid of any implied or stated product or company endorsement. In keeping with its policy of full transparency, the AAFP publicly announced the agreement with the first CAP participant, TCCC. ${ }^{6}$

Throughout development of expanded FamilyDoctor.org content, the AAFP scrupulously adhered to its core principles of separating editorial content from the influence of financial support in the same manner that news outlets separate editorial content from the advertisers who support the publications, Web pages, and broadcasts.

The final result? We publish content on FamilyDoctor.org such as:

There are serious health consequences to consuming added sugar. Too much added sugar in your diet can contribute to tooth decay, obesity, difficulty controlling type 2 diabetes, higher triglyceride levels, lower high-density lipoprotein (HDL, also called "good") cholesterol levels, and heart disease.

Also, if you fill up on foods or beverages that contain added sugar, you are less likely to consume healthy foods and beverages that protect your health. For example, studies have shown that the more sugary beverages (such as soda or juice drinks) people drink, the less milk they drink. Milk provides calcium, protein and vitamins that help your body function well, but soda and juice drinks provide a lot of calories from sugar and little to no nutritional value.

and

To avoid excess added sugar, you should know what foods and drinks are highest in added sugar. Sugary drinks, including soft drinks, sports drinks and fruit drinks, are the number 1 source of added sugar in the American diet. A 12ounce can of non-diet (regular) soda can contain 8 or more teaspoons of sugar and over 130 calories. That's more sugar than the American Heart Association recommends for an average American woman in 1 day! ${ }^{7}$

The AAFP saw a public health and education need that was both unmet and undermined by the barrage of marketing messages and confusing information. We acted to fill that need. In doing so, the AAFP hewed to its high ethical standards, its core values, and its mission in the decisions made and the actions that followed. Readers of Family.Doctor.org will reap the benefits of evidence-based, accurate nutrition information.

These are the facts. They are not a rationalization. Simply because these facts do not comport with others' perceptions or projected motivations does not mean they constitute a conflict of interest or an ethical breach.

To read or post commentaries in response to this article, see it online at http://www.annfammed.org/cgi/content/full/8/4/359.

Key word: Bioethics; conflict of interest; societies; public health

Submitted April 14, 2010; submitted, revised, May 27, 2010; accepted June 1, 2010

Acknowledgments: I am grateful to several anonymous reviewers for this journal for helpful comments.

\section{References}

1. Brody H. Professional medical organizations and commercial conflicts of interest: ethical issues. Ann Fam Med. 2010;8(4):354-358.

1. American Academy of Family Physicians. About us. http://www. aafp.org/online/en/home/aboutus.html?navid=about+us

2. American Academy of Family Physicians. Previous FamilyDoctor.org awards and recognition. http://familydoctor.org/online/famdocen/ home/about/awards/prev-awards.html. Accessed Apr 13, 2010.

3. Flegal KM, Carroll MD, Ogden CL, Curtin LR. Prevalence and trends in obesity among US adults, 1999-2008. JAMA. 2010;303(3):235-241. http://jama.ama-assn.org/cgi/content/full/ 303/3/235?ijkey =ijKHq6YbJn30o\&keytype =refEsiteid = amajnls. Accessed April 13, 2010. Published online Jan 13, 2010.

4. Centers for Disease Control and prevention (CDC). Childhood overweight and obesity. http://www.cdc.gov/obesity/childhood/index. html. Accessed Apr 13, 2010.

5. American Dietetic Association. Nutrition and you: trends 2008: ADA's Consumer Opinion Survey. http://www.eatright.org/Media/ content. aspx?id=7639.

6. American Academy of Family Physicians. Coca-Cola grant launches AAFP Consumer Alliance Program. AAFP News Now. November 6, 2009. http://www.aafp.org/online/en/home/publications/news/ news-now/inside-aafp/20091006cons-alli-coke.html. Accessed Apr 13, 2010.

7. FamilyDoctor.org. Added sugar: what you need to know. http:// FamilyDoctor.org/online/famdocen/home/healthy/food/generalnutrition/1005.html. 